\title{
PERUBAHAN IKLIM, SIAPA YANG BERTANGGUNG JAWAB?
}

\section{CLIMATE CHANGE, WHO IS RESPONSIBLE?}

\author{
Handrix Chris Haryanto ${ }^{1}$, Sowanya Ardi Prahara ${ }^{2}$ \\ ${ }^{1}$ Universitas Paramadina, ${ }^{2}$ Universitas Mercu Buana Yogyakarta \\ ${ }^{1}$ handrixchrisharyanto@gmail.com, ${ }^{2}$ sowanya.harra@gmail.com
}

\begin{abstract}
Abstrak
Perubahan iklim merupakan permasalahan yang mengancam saat ini. Upaya untuk menghadapi permasalahan perubahan iklim ini tidak terlepas dari sejauh mana respon individu yang berkaitan dengan keyakinan individu pada penyebab perubahan iklim. Penelitian ini menggunakan pendekatan kualitatif analisis isi. Studi awal ini bertujuan untuk melihat keyakinan serta atribusi tanggung jawab individu terkait perubahan iklim. Pengumpulan data menggunakan pertanyaan terbuka dengan melibatkan 267 responden. Data dianalisis dengan pendekatan analsis isi induktif. Hasil penelitian menunjukkan bahwa $77 \%$ responden merasa familiar terkait dengan fenomena perubahan iklim dan $72 \%$ mahasiswa yang meyakini bahwa saat ini sedang mengalami permasalahan perubahan iklim yang dipersepsikan dengan 2 indikator terbesar yaitu suhu yang terasa meningkat dan kondisi cuaca saat ini yang tidak menentu. Atribusi tanggung jawab permasalahan mengenai perubahan iklim menurut mayoritas para responden $(98 \%)$ diarahkan pada perilaku individu dibandingkan kententuan takdir. Menurut para responden, upaya menyelesaikan permasalahan perubahan iklim ini adalah perubahan gaya hidup keseharian yang pro terhadap lingkungan.
\end{abstract}

Kata kunci: perubahan iklim, atribusi tanggung jawab, perilaku pro lingkungan.

\begin{abstract}
Climate change is a threatening problem today. The effort to deal with the problem of climate change is inseparable from the extent of individual response related to individual beliefs in the causes of it. This preliminary study addressed the belief and attribution of individuals' responsibilities related to the climate change problems with 267 students as the respondents. The data collection was in open-ended questions and analyzed with the content analysis approach. The results showed that $76 \%$ of the respondents feel familiar with climate change issues, and $72 \%$ of students believe that they are currently experiencing climate change problems, which are perceived by two biggest indicators that are increasing temperature and uncertain current weather conditions. In addition, the attribution of responsibility for climate change issues by the majority of respondents (98\%) is directed at the behavior of individuals compare to destiny. According to the respondents, the effort to solve the problem is to change the daily lifestyle to pro-environmental behavior than to strengthen the environmental laws related to the environment.
\end{abstract}

Keywords: climate change, the attribution of responsibility, pro environmental behavior

\section{PENDAHULUAN}

Permasalahan perubahan iklim atau yang lebih familiar dengan penyebutan climate change merupakan permasalahan global yang pada dasarnya akan mempengaruhi dalam kehidupan manusia. Dalam sebuah studi yang dilakukan oleh The Royal Society dan US National Academy of Science (Wolff, et.al, 2014) memberikan gambaran bahwa permasalahan perubahan iklim ini sudah terjadi sejak era tahun 1900-an. Beberapa indikator yang menjadi perhatian akibat adanya permasalahan perubahan iklim ini terdeteksi dengan adanya peningkatan temperatur hingga 0,8 derajat celcius atau 14 derajat Fahrenheit. Peningkatan tersebut disertai dengan peningkatan suhu 
yang lebih hangat di lautan, pencairan es di kutub dalam jumlah yang cukup besar, terjadinya cuaca yang ekstrim juga menjadi beberapa indikator sedang terjadinya perubahan iklim.

Ancaman akan perubahan iklim memiliki dampak yang nyata serta memberikan efek yang merusak yang berimbas pada kondisi air, habitat, hutan, kesehatan, pertanian dan pesisir (Direktorat Jenderal Pengendalian Perubahan Iklim (Ditjenppi) Kementerian Lingkungan Hidup, 2017). keberadaan perubahan iklim akan menyebabkan penurunan kualitas serta kuantitas air. Kenaikan suhu sebagai situasi ekstrem yang lain akan menurunkan jumlah klorin yang ada dalam air sehingga sangat dimungkinkan akan mempengaruhi tingginya jumlah mikroorganisme yang berbahaya di air. Efek dari perubahan iklim akan menyebabkan pada dua hal yaitu perubahan habitat serta punahnya spesies. Keberadaan kenaikan suhu di bumi, kenaikan batas air laut, terjadinya banjir dan badai sebagai akibat cuaca ekstrem akan membawa dampak perubahan besar terhadap kondisi habitat sebelumnya yang secara alami sebagai tempat tinggal berbagai spesies binatang, tumbuhan maupun organisme yang lain. Dampak perubahan habitat ini tidak terlepas dari rusaknya habitat yang akan mempengaruhi keberlangsungan hidup organisme-organisme yang selama ini bergantung pada habitat tersebut. Punahnya berbagai spesies menjadi ancaman yang nyata ketika habitat menjadi rusak sehingga akan mempengaruhi secara langsung pada ekosistem dan rantai makanan. Kondisi hutan sendiri, ancaman akan perubahan iklim mengarahkan pada permasalahan kualitas dan kuantitas hutan serta meningkatnya gas rumah kaca akibat deforestasi. Keberadaan perubahan iklim mengarahkan pada cuaca yang ekstrem salah satunya kemarau. Keberadaan kemarau yang ekstrem ini bisa mengakibatkan terjadinya kebakaran hutan. Dengan permasalahan kebakaran ini hutan tidak lagi mampu berfungsi dengan baik sebagai paru-paru dunia dengan memproduksi $\mathrm{O} 2$ dan membantu menyerap gas rumah kaca maupun karbondioksida sebagai penyebab terjadinya pemanasan global. Berkaitan dengan kesehatan, penyebaran wabah penyakit seperti malaria, kolera, maupun demam berdarah mudah meningkat saat kenaikan curah hujan. Keberadaan penyakit tersebut juga berkembang biak pada saat cuaca panas dan lembab yang mana kondisi tersebut merupakan efek dari perubahan iklim. Untuk kondisi pertanian, permasalahan perubahan iklim dapat berimbas pada berkurangnya area pertanian serta produktivitas pertanian. Hal ini tidak terlepas dari efek kenaikan suhu yang bisa memicu kemarau panjang sehingga berkurangnya air untuk perairan pertanian. Selain hal tersebut, perubahan iklim dapat memicu bencana alam lain yaitu banjir akibat adanya curah hujan. Dengan kedua kondisi bencana tersebut dapat menjadikan areal pertanian menjadi tidak produktif serta rusak. Untuk permasalahan terakhir dan tidak kalah penting menjadi perhatian terkait dengan keberadaan pesisir. Kondisi pesisir ini tidak terlepas dari tenggelamnya sebagian daerah pesisir maupun pulau-pulau kecil. Kenaikan suhu bumi yang menyebabkan mencairnya es di kutub meningkatkan permukaan air laut yang dapat menenggelamkan daerah pesisir maupun pulau-pulau terkecil.

Ancaman-ancaman yang sudah dipaparkan sebelumnya menjadi permasalahan yang nyata khususnya di Indonesia. Seperti halnya juga menjadi fokus perbaikan yang dilakukan oleh 
pemerintah baik melalui Kementerian Lingkungan Hidup maupun Kementerian PPN/Bappenas (Perencanaan Pembangunan Nasional). Kementerian Lingkungan Hidup melalui Peraturan Menteri Lingkungan Hidup dan Kehutanan Republik Indonesia tahun 2016 (Ditjenppi, 2018) menyusun Pedoman Penyusunan Aksi Adaptasi Perubahan Iklim yang substansinya mencakup 5 hal yaitu pertama, identifikasi target cakupan wilayah dan/atau sektor spesifik dan masalah dampak perubahan iklim; kedua, penyusunan kajian kerentanan dan risiko iklim; ketiga, penyusunan pilihan aksi adaptasi perubahan iklim; keempat, penetapan prioritas aksi adaptasi perubahan iklim; dan kelima pengintegrasian aksi adaptasi perubahan iklim ke dalam kebijakan, rencana, dan/atau program pembangunan. Peraturan tersebut, dalam tiga tahun setelah disahkannya pedoman tersebut, capaian Kementerian Lingkungan Hidup dalam penanganan perubahan iklim terlihat dalam paparannya dalam mengimplementasikan Paris Agreement dan Pencapaian Target National Determined Contribution (NDC) dalam acara Festival Iklim 2018 yang digelar oleh Kementerian Lingkungan Hidup dan Kehutanan (PPID Kementerian Lingkungan Hidup dan Kehutanan, 2018). Kementerian Lingkungan Hidup dan Kehutanan telah mencapai beberapa kemajuan yaitu telah tersusunnya instrumen kebijakan dan pelaksanaan aktivitas adaptasi dan mitigasi perubahan iklim hingga tingkat lapangan (tapak) berupa peraturan pemerintah, sistem informasi, sistem registri, cara-cara penilaian dan pengukuran emisi GRK, hingga pembangunan program kampung iklim.

Pemerintah pada dasarnya sudah memiliki infrastruktur yang kuat berupa sistem, aturan, maupun kebijakan dalam menghadapi ancaman perubahan iklim. Permasalahan yang perlu diperhatikan saat ini yaitu keberadaan individu terkait peran aktif yang memberikan dampak nyata melalui perilaku. Clayton, dkk. (2015) menjelaskan keterkaitan penyelesaian masalah perubahan iklim dengan perilaku manusia. Perilaku akan menjadi sumber utama dalam memahami sejauh mana sebuah aturan, teknologi maupun sistem dapat berjalan dengan efektif dan baik. Perilaku individu yang tidak mampu beradaptasi mengikuti teknologi, sistem maupun aturan yang sudah dibangun sebelumnya untuk menghadapi sebuah ancaman perubahan iklim, maka keberadaan infrastruktur aturan tersebut menjadi tidak efektif. Perilaku manusia menjadi respon yang akan mengarahkan pada sebuah potensi gelombang massal dalam memaksimalkan hasil menghadapi ancaman perubahan iklim.

Perilaku individu yang mengarahkan pada upaya menghadapi permasalahan perubahan iklim ini dipengaruhi beberapa hal yaitu keyakinan yang kuat bahwa perubahan iklim sedang terjadi saat ini (Milfont, Milojev, Greaves, \& Sibley, 2015; Haryanto \& Prahara, 2017) serta pemahaman individu mengenai sejauh mana penyebab munculnya permasalahan perubahan iklim serta siapa yang harus bertanggung jawab dalam menangani permasalahan. Perilaku tersebut diistilahkan dengan atribusi tanggung jawab (Swim, Clayton, \& Howard, 2011; Jang, 2013). Keberadaan aspekaspek tersebut menurut Weber (2010) dapat menjadi motif yang sangat kuat dalam upayanya menstimulasi munculnya aksi baik yang bersifat personal maupun kolektif dalam upayanya merespon permasalahan perubahan iklim. 
Keyakinan keyakinan sendiri, Milfont, dkk., (2015) menggambarkan lebih lanjut bahwa ketika individu memiliki keyakinan yang kuat bahwa perubahan iklim sedang terjadi saat ini maka akan menjadi faktor yang penting untuk menggerakkan individu merespon permasalahan perubahan iklim tersebut. Untuk aspek atribusi tanggung jawab yang erat kaitannya dengan bagaimana individu melihat keberadaan faktor penyebab pihak yang bertanggung jawab untuk permasalahan perubahan iklim dapat dilihat dari dua sudut pandang yaitu apakah perubahan iklim memang karena faktor alam semata (natural) atau efek dari perilaku manusia yang tidak ramah terhadap alam. Pemahaman tersebut pada dasarnya akan mempengaruhi sejauh mana keyakinan individu terkait dengan situasi yang dapat dikontrol maupun tidak. Seperti halnya dijelaskan dalam kajian yang sudah dilakukan oleh Gifford, Kormos dan McIntyre (2011) serta Jang (2013) yaitu ketika individu meyakini bahwa permasalahan perubahan iklim ini lebih disebabkan karena faktor alam maka akan menguatkan keyakinan bahwa permasalahan yang sedang dihadapi merupakan sesuatu yang di luar kontrol manusia. Ketika individu meyakini bahwa permasalahan lingkungan yang sedang dihadapi tersebut merupakan situasi di luar dari kontrol kemampuan sebagai manusia maka akan menjadi penghalang internal dalam meningkatkan motivasi individu untuk bertindak memberikan solusi. Kondisi tersebut menurut Heath dan Gifford (2006) tidak terlepas dari sejauh mana keyakinan individu terhadap aksi yang akan dilakukan nantinya memberikan efek secara nyata atau tidak.

Mendasarkan pada pembahasan mengenai "insfrastruktur" di awal yaitu berupa aturan maupun kebijakan yang sudah ada, maka keberadaan respon perilaku yang didasarkan pada keyakinan serta atribusi terhadap permasalahan perubahan iklim ini sebagai daya dorong dalam memunculkan respon yang tepat perlu dikaji lebih jauh khususnya di Indonesia saat ini. Hal ini tidak terlepas dari upaya untuk mendeskripsikan jarak permasalahan yang sebenarnya terjadi agar nantinya kebijakan yang sudah tersusun dapat diimplementasikan dan mendapatkan dukungan secara masif di masyarakat. Poin utamanya berupa apakah memang masyarakat Indonesia saat ini meyakini bahwa perubahan iklim sedang terjadi serta siapa yang bertanggung jawab atas munculnya permasalahan perubahan iklim saat ini sehingga sangat dimungkinkan menjadi dasar salah satu kesimpulan apakah masyarakat siap dan mampu terlibat dalam menghadapi permasalahan perubahan iklim saat ini.

\section{METODE}

Responden dalam penelitian ini yaitu mahasiswa yang sedang melakukan studi di Jakarta dan Yogyakarta. Dalam hal ini melibatkan mahasiswa sejumlah 267 responden dengan rentang usia 17-30 tahun. Penelitian ini menggunakan pendekatan kualitatif analisis isi. Kualitatif analisis isi sendiri menurut Hsieh dan Shannon (2005) diarahkan pada upaya peneliti untuk melakukan interpretasi secara subyektif dari data yang bersifat tekstual. Dalam hal ini keberadaan data yang bersifat tekstual dapat diperoleh dengan menggunakan pertanyaan terbuka. Reja, Manfreda, 
Hlebec, dan Vehovar, (2003) menjelaskan bahwa menggunakan pertanyaan terbuka sebagai instrumen pengambilan data memiliki kelebihan disebabkan dapat mendapatkan jangkauan subyektif responden yang lebih luas terhadap tujuan penelitian serta dimungkinkan dapat memaknai lebih jauh terhadap respon yang diberikan oleh reponden. Selain itu, penggunaan pertanyaan terbuka sangat dimungkinkan untuk menghindari bias yang mungkin saja terjadi ketika responden dihadapkan dengan pertanyaan tertutup.

Untuk analisis data yang digunakan dalam penelitian ini bersifat induktif yang mana menurut Ello dan Kyngäs (2008) lebih menekankan pada hasil kesimpulan mendasarkan pada pemaknaan peneliti terhadap jawaban responden dibandingkan mengacu pada teori yang sudah ada. Dalam analisis yang bersifat induktif ini peneliti melakukan 3 tahapan analisis yaitu open coding, kategorisasi dan abstraksi. Pada tahapan open coding peneliti memberikan catatan-catatan tertentu pada jawaban yang sudah diberikan oleh responden. Catatan-catatan tersebut nantinya akan diarahkan pada upaya peneliti mencari kata kunci dalam memaknai jawaban responden. Setelah tahapan pertama dilakukan, maka selanjutnya peneliti masuk ke dalam tahap kategorisasi. Dalam tahap ini peneliti mengelompokkan kata kunci yang sudah didapatkan sesuai dengan kesamaan pemaknaan. Dalam tahap kategorisasi ini peneliti akan memunculkan tema yang lebih besar berdasarkan pada pengelompokkan tersebut. Setelah tahap pengelompokkan diselesaikan maka peneliti akan masuk ke dalam tahapan abstraksi yang mengarahkan pada pembuatan kesimpulan berdasarkan pada tema serta tujuan penelitian yang sudah dibuat sebelumnya. Dalam penelitian ini keterpercayaan hasil penelitian didasarkan pada teknik umum yang dilakukan dalam penelitian kualitatif. Penelitian ini mendasarkan pada teknik intecoder agreement yang mana menurut Creswell (2009) diarahkan pada pemeriksaan ulang serta silang untuk mendapatkan kesepakatan dalam memberikan pemaknaan pada jawaban responden.

\section{HASIL DAN PEMBAHASAN}

Berdasarkan pada hasil penelitian diketahui bahwa dari 267 responden menyatakan bahwa 192 responden (72\%) meyakini bahwa saat ini perubahan iklim sedang terjadi, 59 responden (22\%) menyatakan ragu-ragu dan 16 responden (6\%) menyatakan tidak meyakini bahwa saat ini sedang terjadi perubahan iklim. Dari $72 \%$ responden yang meyakini saat ini sedang terjadi perubahan iklim menjelaskan bahwa 2 indikator terbesar perubahan iklim yang dirasakan berupa cuaca tidak menentu yang dijawab oleh $38 \%$ responden dan peningkatan suhu yang dijawab oleh $37 \%$ responden. Untuk jawaban secara lengkap dapat dilihat pada tabel 1 terkait dengan indikator perubahan iklim yang dirasakan oleh individu saat ini. 
Tabel 1. Indikator yang dirasakan sebagai bentuk terjadinya perubahan iklim

\begin{tabular}{ll}
\hline Kategori & Persentase \\
\hline Cuaca tidak menentu & $38 \%$ \\
Suhu meningkat & $37 \%$ \\
Rusaknya lingkungan & $6 \%$ \\
Banyak terserang penyakit & $4 \%$ \\
Bencana meningkat & $4 \%$ \\
Curah hujan tinggi & $2 \%$ \\
Other (jawaban ambigu) & $5 \%$ \\
Blank (tidak memnerikan jawaban) & $4 \%$ \\
\hline
\end{tabular}

Berkaitan dengan atribusi tanggung jawab terjadinya perubahan iklim menurut responden yang merasa bahwa perubahan iklim sedang terjadi didapatkan hasil bahwa 98\% responden menyatakan disebabkan oleh perilaku manusia dan $2 \%$ responden menyatakan disebabkan oleh takdir. Beberapa jawaban yang menggambarkan kategori tersebut dapat dilihat sebagai berikut:

Tabel 2. Pernyataan responden terkait atribusi tanggung jawab terjadinya perubahan iklim Atribusi tanggung jawab terjadinya perubahan iklim

R1 : "Perilaku masyarakat yang kurang memiliki kesadaran terkait lingkungan."

R51: "Tanggung jawab masyarakat karena kurangnya pemahaman dan kesadaran diri dalam menjaga lingkungan, dan tanggung jawab pemerintah dalam memberikan sosialisasi atas uu yg dibuat, karena bukan tidak mungkin masyarakat juga belum mengetahui ataupun sadar pentingnya menjaga lingkungan karena pemerintah tidak melaksanakan tugasnya dengan baik." R89 : "Semua orang."

R108: "Semua orang harus ikut bertanggung jawab dengan permasalahan iklim"

R169: "Yang paling bertanggung jawab adalah seluruh masyarakat termasuk pemerintah, harus ada kesadaran diri dari masing-masing individu untuk mengetahui bencana apa yang akan datang ketika melakukan itu" R45 : "Bukan tanggung jawab siapapun karena hal ini sudah menjadi takdir."

Lebih lanjut menurut responden yang merasa bahwa perubahan iklim sedang terjadi ini upaya untuk bisa mengatasi permasalahan tersebut mayoritas responden sebanyak $73 \%$ menyatakan bahwa perlu adanya peningkatan kesadaran terkait dengan perilaku pro lingkungan, $16 \%$ responden menyatakan perlu adanya penguatan teknologi yang ramah lingkungan, 7\% responden menyatakan perlu adanya penguatan undang-undang terkait lingkungan sebagai regulasi dalam negeri, $1 \%$ responden menyatakan perlu adanya penguatan infrastruktur berkaitan dengan penghijauan dan sebanyak 3\% responden memberikan jawaban yang dirasa tidak sesuai dengan pertanyaan. Hasil penelitian lainnya yang berkaitan dengan upaya yang dianggap sudah maksimal dilakukan oleh para responden terkait dengan berkontribusi dalam menghadapi permasalahan lingkungan hidup yaitu menjaga kebersihan lingkungan sekitar sebanyak $63 \%$ responden, mengikuti organisasi lingkungan hidup sebanyak $10 \%$ responden, sering mengikuti seminar/diskusi terkait dengan lingkungan hidup sebanyak $8 \%$ responden, memberikan donasi untuk gerakan lingkungan hidup sebanyak $7 \%$, tidak membuang sampah sembarangan sebanyak $3 \%$ responden, membatasi 
penggunaan kendaraan bermotor sebanyak $1 \%$ responden dan sebanyak $8 \%$ responden memberikan jawaban yang tidak sesuai dengan pertanyaan.

Hasil selanjutnya menunjukkan bahwa dari para responden yang merasa bahwa saat ini perubahan iklim sedang terjadi, 93\% responden menyatakan tertarik dengan informasi atau berita yang terkait dengan permasalahan iklim dan lingkungan hidup dan hanya $7 \%$ responden yang menyatakan tidak tertarik dengan informasi tersebut. Eksplorasi lebih lanjut memperlihatkan bahwa $69 \%$ responden menyatakan bisa secara aktif mencari informasi yang terkait dengan permasalahan iklim dan lingkungan hidup 1-3 kali dalam seminggu, 8\% responden menyatakan bisa mencari informasi tersebut lebih dari 3 kali dalam seminggu serta $23 \%$ responden menyatakan tidak pernah secara aktif mencari informasi berkaitan dengan permasalahan iklim dan lingkungan hidup. Berkaitan dengan pemahaman responden terhadap peraturan pemerintah dalam penanganan perubahan iklim hanya $8 \%$ responden yang merasa bahwa pemerintah sudah memiliki peraturan tersebut, $42 \%$ responden menyatakan pemerintah belum memiliki peraturan tersebut dan $50 \%$ responden merasa ragu-ragu apakah pemerintah sudah memiliki atau belum terkait peraturan tersebut.

Berdasarkan pada hasil penelitian menunjukkan bahwa sebanyak $72 \%$ responden menyakini bahwa saat ini perubahan iklim memang sedang terjadi. Hal ini sejalan dengan beberapa penelitian oleh Haryanto dan Prahara (2017) terkait dengan keyakinan responden sedang terjadinya perubahan iklim yang mencapai 94\%. Hasil riset dari The Brown International Andvanced Research Institute (BIARI) pada tahun 2014 dengan responden mahasiswa juga memberikan gambaran keyakinan di beberapa negara terkait dengan perubahan iklim diantaranya yaitu Brazil yang mencapai $94,6 \%$, Cina yang mencapai $91,7 \%$ serta Filipinan yang mencapai 95\%. Meskipun begitu, hasil penelitian ini sedikit menunjukkan perbedaan terkait besaran persentase keyakinan terhadap perubahan iklim di wilayah negara-negara tropis yang bisa mencapai $90 \%$. Untuk indikator terjadinya perubahan iklim yang dirasakan oleh responden sendiri mayoritas jawaban yang muncul berupa cuaca yang tidak menentu (38\%) serta suhu yang meningkat (37\%). Keberadaan dua indikator besar tersebut pada dasarnya sudah dipaparkan dalam studi efek perubahan iklim yang telah dilakukan oleh para ahli ekologi yang diantaranya laporan pada tahun 2014 IPCC (Corlett, 2014) dengan melihat kondisi yang terjadi di wilayah tropis

Hasil penelitian juga menunjukkan bahwa $98 \%$ responden dalam penelitian ini meyakini bahwa perubahan iklim yang terjadi saat ini diakibatkan oleh perilaku manusia itu sendiri dan $2 \%$ responden meyakini dikarenakan takdir. Mayoritas responden (73\% responden) dalam penelitian juga berpendapat bahwa solusi yang tepat untuk dilakukan yaitu peningkatan kesadaran perilaku pro lingkungan dibandingkan penguatan teknologi ramah lingkungan, penguatan undang-undang maupun penguatan infrastruktur terkait penghijauan. Hasil penelitian ini pada dasarnya membangun sebuah asumsi positif dalam artian ada potensi untuk bisa menggerakkan secara massal dalam menangani permasalahan perubahan iklim yang sedang terjadi saat ini. Asumsi 
tersebut mendasarkan pada penelitian yang sudah dilakukan oleh Gifford, dkk. (2011) maupun Jang (2013) yang memberikan gambaran bahwa motivasi untuk bertindak dalam menangani permasalahan perubahan iklim ini dipengaruhi oleh sejauh mana individu mempersepsikan bahwa tindakannya dapat memberikan efek secara langsung maupun tidak langsung. Permasalahan perubahan iklim yang dipersepsikan sebagai akibat dari perilaku manusia dibandingkan karena takdir mengarahkan pada keyakinan bahwa keberhasilan di dalam menangani permasalahan tersebut sangat dipengaruhi oleh faktor internal yang dapat dikendalikan dibandingkan faktor eksternal yang sulit untuk dikontrol.

Meskipun begitu, penelitian lanjutan masih perlu dilakukan terkait dengan motivasi dan keyakinan. Penelitian yang dilakukan oleh Brenkert-Smith, Meldrum dan Champ (2015) memberikan hasil bahwa adanya hubungan yang lemah pada responden yang meyakini adanya perubahan iklim dan salah satunya meyakini bahwa perubahan iklim disebabkan oleh perilaku manusia tidak serta merta akan meningkatkan motivasi dalam melakukan mitigasi terhadap bencana. Perlu adanya penelitian lebih jauh terkait dengan batasan-batasan yang lebih jelas sejauh mana motivasi tersebut serta jenis perilaku mitigasi terkait bencana yang disebabkan oleh perubahan iklim.

Hasil penelitian yang mengarahkan pada peningkatan kesadaran perilaku pro lingkungan sebagai solusi yang dianggap tepat dalam menghadapi perubahan iklim saat ini juga sejalan dengan beberapa penelitian yang sudah dilakukan sebelumnya. Diantaranya penelitian oleh Leiserowitz, dkk., (Koger, Leslie \& Hayes, 2011) yang menjelaskan hasil studinya bahwa $61 \%$ dari respondennya menyatakan bahwa perubahan gaya hidup yang siginifikan dianggap lebih penting dibandingkan pendekatan teknologi dalam menghadapi perubahan iklim. Koger, dkk., (2011) sendiri menekankan keberadaan gaya hidup ini diarahkan dalam bentuk perilaku pro lingkungan. Williamson, Satre-Meloy, Velasco dan Green (2018) sendiri melihat permasalahan perubahan iklim ini tidak terlepas dari meningkatnya jumlah emisi gas dalam kurun seabad ini. Jumlah emisi gas yang tinggi ini disadari maupun tidak merupakan hasil dari perilaku manusia itu sendiri. Penurunan emisi gas merupakan upaya yang harus menjadi fokus sebagai salah satu solusi yang harus dilakukan yaitu berkaitan dengan perilaku makan yang tidak merusak (seperti mengurangi membuang makanan dan mengurangi makan daging), peningkatan pertanian serta manajemen lahan yang tepat (seperti melakukan penanaman pohon dan mengurangi penggunaan pupuk di lahan pertanian), perilaku penggunaan transportasi yang tepat (seperti penggunaan kendaraan umum dan beralih menggunakan sepeda ketika di dalam kota daripada menggunakan mobil), dan perilaku terkait dengan penggunaan energi dan material (seperti perilaku recycle pada kertas, plastik dan material lain serta menggunakan lampu yang hemat energi). Jika perilaku-perilaku pro lingkungan tersebut dapat dilakukan dengan baik maka dapat memberikan pengaruh pada penurusan emisi gas saat ini dari 19,9\% hingga $36,8 \%$. 
Menjadi perhatian selanjutnya Menurut mayoritas responden, perilaku pro lingkungan sebagai solusi dalam menghadapi permasalahan perubahan iklim adalah menjaga kebersihan lingkungan sekitar, diikuti mengikuti organisasi lingkungan hidup, sering mengikuti seminar/diskusi terkait dengan lingkungan hidup, memberikan donasi untuk gerakan lingkungan hidup, tidak membuang sampah sembarangan, dan membatasi penggunaan kendaraan bermotor.

Mengacu pada kajian yang dijelaskan oleh Karp (1996) dan Larson, Stedman, Cooper dan Decker (2015) mengenai level perilaku pro lingkungan dapat diketahui bahwasanya mayoritas responden dalam penelitian ini masih dalam level dasar yang menekankan pada lingkup yang masih terbatas pada dirinya sendiri. Karp (1996) menyatakan bahwa level dasar perilaku pro lingkungan ini berupa good citizens yaitu seperti 3R (reduce, reuse dan recycle), hemat dalam penggunaan listrik dan air, mengurangi penggunaan kendaraan pribadi, mengurangi penggunaan kendaraan bermotor, tidak merokok, menghindari pembakaran sampah. Larson, dkk., (2015) menjelaskan untuk level dasar perilaku pro lingkungan ini berupa conservation lifestyle yang pada dasarnya menekankan pada perilaku-perilaku yang biasa dilakukan pada kehidupan sehari-hari.

Berdasarkan hasil penelitian ini, perilaku pro lingkungan yang dianggap memiliki tingkatan yang lebih tinggi yaitu mengikuti organisasi lingkungan hidup, sering mengikuti seminar/diskusi terkait dengan lingkungan hidup, memberikan donasi untuk gerakan lingkungan hidup. Hal ini sesuai dengan pendapat Karp (1996) dan Larson, dkk., (2015) bahwa perilaku pro lingkungan yang tinggi tingkatannya akan mengarahkan pada perilaku yang tidak hanya berorientasi pada diri pribadi tetapi pada sebuah gerakan yang dianggap memiliki efek yang lebih masif dan besar. Perilaku-perilaku tersebut menurut Karp (1996) dapat dimasukkan ke dalam level activist yang menekankan pada perilaku yang membutuhkan investasi besar di dalam melakukannya. Larson, dkk., (2015) sendiri memasukkan perilaku-perilaku tersebut sebagai social environmentalism dan environmental citizenship. Social environmentalism ini dijelaskan sebagai perilaku yang akan berimbas pada munculnya sebuah interaksi maupun komunikasi antar individu dalam upayanya mengajak orang lain untuk berperilaku yang sama yaitu pro lingkungan. Environmental citizenship sendiri mengarahkan pada lingkup yang lebih luas yaitu diantaranya berupa donasi maupun ikut langsung dalam sebuah gerakan maupun terlibat secara politik seperti memberikan suara maupun ikut dalam membuat kebijakan yang pro terhadap lingkungan.

Mayoritas responden (93\% responden) menyatakan tertarik dengan informasi yang berkaitan dengan perubahan iklim maupun masalah lingkungan dan sebanyak $77 \%$ responden menyatakan secara aktif mencari informasi tersebut. Hasil penelitian lainnya menunjukkan bahwa hanya $8 \%$ responden yang merasa bahwa pemerintah sudah memiliki peraturan yang berkaitan dengan penangangan yang berkaitan dengan permasalahan perubahan iklim ini. Keberadaan informasi ini pada dasarnya menguatkan pengetahuan individu terhadap sebuah permasalahan perubahan iklim ini yang nantinya akan berimbas pada sejauh mana keinginan untuk terlibat serta perilaku individu dalam menghadapi permasalahan perubahan iklim. Menurut Lorenzoni, dkk., (Gifford, Kormos \& 
McIntyre, 2011), kekurangan pengetahuan ini merupakan salah satu penghalang secara psikologis yang bersifat individual di dalam memunculkan perilaku yang tepat dalam menghadapi permasalahan perubahan iklim ini. Gifford (Gifford, dkk., 2011) menjelaskan lebih jauh bahwa kesadaran berkaitan dengan permasalahan perubahan iklim ini tidak terlepas dari kurangnya pengetahuan terkait dengan perilaku mitigasi terhadap permasalahan perubahan iklim yang spesifik, bagaimana caranya melakukan perilaku tersebut, serta manfaat yang bisa diperoleh dari perilaku mitigasi tersebut. Mendasarkan pada hasil penelitian yang ada bisa dilihat bahwa meskipun mayoritas responden sudah menyatakan tertarik serta memiliki keaktifan dalam mencari informasi, namun masih perlu dilakukan kajian mendalam berkaitan dengan jenis informasi serta seberapa jauh pengetahuan responden berkaitan dengan perubahan iklim itu sendiri serta perilaku mitigasi.

\section{KESIMPULAN}

Hasil penelitian menunjukkan bahwa mayoritas responden (72\% responden) memiliki keyakinan bahwa saat ini permasalahan perubahan iklim sedang terjadi dengan mendasarkan pada indikator terbesarnya yaitu cuaca yang tidak menentu serta peningkatan suhu saat ini. Hasil penelitian ini perlu dilakukan kajian lebih mendalam terkait dengan hasil penelitian lain yang menyebutkan untuk responden di wilayah tropis biasanya memiliki keyakinan yang tinggi hingga mencapai 90\%. Terkait atribusi terhadap permasalahan perubahan iklim, mayoritas responden menyatakan bahwa kondisi yang terjadi saat ini disebabkan oleh perilaku manusia itu sendiri. Responden juga meyakini bahwa perubahan gaya hidup yang mengarahkan pada perilaku pro lingkungan menjadi solusi yang tepat. Keberadaan perilaku pro lingkungan yang sudah dilakukan oleh responden saat ini mayoritas masih berada pada level dasar yang ke depannya diperlukan sebuah intervensi yang masif agar meningkat pada level yang lebih tinggi. Keberadaan motivasi responden dalam mencari informasi meski dapat dikatakan baik namun perlu dilakukan kajian mendalam berkaitan dengan seberapa jauh pengetahuan responden terkait permasalahan perubahan iklim serta perilaku mitigasi yang dipahami.

Penelitian yang bersifat pendahuluan ini pada dasarnya masih bersifat deskriptif dan masih diperlukan penyempurnaan penelitian lanjutan secara kuantitatif dengan pengujian hipotesis baik berupa korelasi maupun pengaruh antar variabel maupun perbedaan antar demografis responden penelitian seperti berdasarkan pada temuan awal yang sudah di dapatkan. Penambahan yang lebih detail terkait dengan informasi responden juga dapat dilakukan seperti misalnya menambahkan kondisi wilayah responden apakah perkotaan atau pedesaan, daerah dekat pantai atau tengah kota maupun daerah indutri besar atau tidak yang pada dasarnya dapat merasakan dampak yang berbeda untuk permasalahan perubahan iklim ini khususnya berkaitan dengan permasalahan emisi gas. 


\section{DAFTAR PUSTAKA}

Brenkert-Smith, H., Meldrum, J. R., \& Champ, P. A. (2015). Climate change beliefs and hazard mitigation behaviors: homeowners and wildfire risk. Environmental Hazards, 14(4), 341360. http://dx.doi.org/10.1080/17477891.2015.1080656.

Clayton, S., Devine-Wright, P., Stern, P., S., Whitmarsh, P., Carrico, A., Steg, L., Swim, J., \& Bonnes, M. (2015). Psychological research and global climate change. Nature Climate Change, 5, 640-646. doi: 10.1038/nclimate2622.

Corlett, R. T. (2014). The impacts of climate change in the Tropics. https://www.jcu.edu.au/stateof-the-tropics/publications/2014/2014-essay-pdfs/Essay-2-Corlett.pdf

Creswell, J. W. (2009). Research design: Qualitative, quantitative, and mixed methods approaches 3rd ed. California: Sage Publications.

Ditjenppi Kementerian Lingkungan Hidup dan Kehutanan. (2016). Perubahan iklim, perjanjian paris dan nationally determined contribution. Jakarta: Kementerian Lingkungan Hidup dan Kehutanan.

Anonym. (2017). Dampak dan fenomena perubahan iklim. http://ditjenppi.menlhk.go.id/kcpi/index.php/info-iklim/dampak-fenomena-perubahaniklim/229-perubahan-iklim-di-indonesia\#.

Anonym. (2018). Telah terbit pedoman penyusunan aksi adaptasi perubahan iklim. http://ditjenppi.menlhk.go.id/index.php/berita-ppi/2714-telah-terbit-pedoman-penyusunanaksi-adaptasi-perubahan-iklim\#.

Elo, S. \& Kyngäs, H. (2008). The qualitative content analysis process. Journal of Advanced Nursing, 62(1), 107-115. doi: 10.1111/j.1365-2648.2007.04569.x.

Gifford, R., Kormos, C., \& McIntyre, A. (2011). Behavioral dimensions of climate change: drivers, responses, barriers, and interventions. Climate Change, 2(6), 801-827. doi: 10.1002/wcc.143.

Haryanto, H. C., \& Prahara, S. A. P. (2017). Yakinkah dengan adanya perubahan iklim?. INQUIRY: Jurnal Ilmiah Psikologi, 8(2), 88-99.

Heat, Y., \& Gifford, R. (2006). Free-market ideology and environmental degradation: The case of belief in global climate change. Environment and Behavior, 38(1), 48-71. doi: $10.1177 / 0013916505277998$.

Hsieh, H-F., \& Shannon, S. E. (2005). Three approaches to qualitative content analysis. Qualitative Health Research, 15(9), 1277-1288. doi: 10.1177/1049732305276687.

Jang, S. M. (2013). Framing responsibility in climate change discourse: Ethnocentric attribution bias, perceived causes, and policy attitudes. Journal of Environmental Psychology, 36, 2736. doi: 10.1016/j.jenvp.2013.07.003.

Karp, D., G. (1996). Values and their effect on pro environmental behavior. Environment and Behavior, 28(1), 111-133. doi: 10.1177/0013916596281006.

Koger, S. M., Leslie, K. E., \& Hayes, E. D. (2011). Climate change: Psychological solutions and strategies for change. Ecopsychology, 3(4), 227-235. DOI: 10.1089/eco.2011.0041.

Larson, L., R., Stedman, R., C., Cooper, C., B., \& Decker, D., J. (2015). Understanding the multidimensional structure of pro-environmental behavior. Journal of Environmental Psychology, 43, 112-124. doi: 10.1016/j.jenvp.2015.06.004.

Milfont, T., L., Milojev, P., Greaves, L., M., Sibley, C., G. (2015). Socio-cultural and psychological foundations of climate change beliefs. New Zealand Journal of Psychology, 44(1), 17-30.

PPID Kementerian Lingkungan Hidup dan Kehutanan. (2018). Tiga tahun capaian pengendalian perubahan iklim. http://ppid.menlhk.go.id/berita_foto/browse/975. 
Reja, U., Manfreda, K. L., Hlebec, V., \& Vehovar, V. (2003). Open-ended vs Close-ended Question in Web Questionnaires. Advances in Methodology and Statistics, 19, 59-177.

Swim, J., Clayton, S., \& Doherty, T. (2011). Psychology and global climate change: Addressing a multi faceted phenomenon and set of challenges. https://www.apa.org/science/about/publications/climate-change.pdf.

The Brown International Advanced Research Institute. (2014). An international survey initiative on "students, consumption, and environment". http://watson.brown.edu/biari/files/biari/imce/BIARI\%20Survey\%20Project\%20Narrative\% 20Report-Final-06172014.pdf

Weber, E. U. (2010). What shapes perceptions of climate change?. Climate Change, 1(3), 332-342. doi: $10.1002 /$ wcc. 41 .

Williamson, K., Satre-Meloy, A., Velasco, K., \& Green, K. (2018). Climate change needs behavior change: Making the case for behavioral solutions to reduce global warming. Arlington, VA: Rare

Wolff, E., Fung, I., Hoskins, B., Mitchell, J., Palmer, T., Santer, B., Shepherd, J., Shine, K., Solomon, S., Trenberth, K., Walsh, J., \& Wuebbles, D. (2014). Climate change: Evidence and Causes. http://dels.nas.edu/resources/static-assets/exec-office-other/climate-changefull.pdf. 